\title{
Educating for Environmental Practices: An Assessment from Bachelor of Commerce (B. Com) Undergraduates in Sri Lankan State Universities
}

\author{
K. M. V. Sachitra \\ University of Sri Jayewardenepura, Sri Lanka \\ D. G. P. Kaluarachchi \\ Eastern University, Sri Lanka
}

\begin{abstract}
Scholarly attention on environmental literacy has been increased in recent years since the knowledge level and interest in environmental issues are decisive to engage in environmental protection functions. The study aims to investigate the environmental literacy level believing that understanding the level of environmental literacy will lead to influence attitudinal changes and actions of undergraduates towards environment. Total number of 650 Bachelor of Commerce undergraduates in state universities of Sri Lanka were selected as the sample of the study. A self-administered structured questionnaire was administered to collect data on the environmental literacy level, the interest and the activity engagement in environmental activities of the respondents. The regression-based path analysis was performed to examine the relationships among the constructs. Based on the descriptive analysis, there was low level of environmental literacy of the selected undergraduates in this study. The overall level of interest in environmental issues and the level of engagement in environmental activities were moderate. The regression-based path analysis indicated that environmental literacy as well as the environmental interest were significant
\end{abstract}

\section{Corresponding Author:}

Ms. K. M. V. Sachitra is a Senior Lecturer at the Department of Commerce, University of Sri Jayewardenepura, Sri Lanka. E-mail: vilani@sjp.ac.lk 
predictors for environmental engagement. Further, interest in environmental issues mediated the relationship between the environmental literacy and the actual engagement in environmental activities. The study exclusively examined the relationship between the undergraduates' knowledge level of the environment and the interest in environmental issues and also examined the factors that influence undergraduates' participation in activities that promote sustainability of the environment, which has been neglected by prior studies. The results facilitate to recommend that the degree programmes should be integrated with environmental areas where such knowledge could lead to promote the interest and the action towards the environmental activities.

\section{Keywords}

Bachelor of Commerce undergraduates, Comparative study, Environmental literacy, Sustainability

\section{Introduction}

It is essential to have a healthy and productive environment in order to achieve sustainable human events (Roth, 1992). Hence, awareness of environmental issues and the actions taken to protect environment are essential for every individual, corporation and society. To protect and retain a sustainable environment, there is a need to have an adequate knowledge about the environment (Owusu, Kwakya, Welbeck, \& Ofori, 2017). Behavioural approaches highlight that more the opportunities to enhance knowledge, the easier it is to change behaviour (Hungerford \& Volk, 1990).In this regard, scholarly attention on environmental literacy has increased in recent years since the knowledge level and interest in environmental issues are decisive to engage in environmental protection functions (Campbell-Arvai, 2015; Eagle, Low, Case, \& Vandommele, 2015; Hartman, Demars, Griscom, \& Butner, 2017; Owusu et al., 2017). According to Goldman, Yavetz and Peer(2006), in order to achieve a sustainable environment, environmental literacy level of the society needs to be upgraded. To do so, education is a key factor, as the education systems provide people with the basic understandings and skills that require to interact and interrelate between them and the environment (Roth, 1992).

Thus, education has been suggested as key to a transformational change towards the environment (Frisk \& Larson, 2011). As Petocz and Dixon 
(2011) mentioned, students gain both discipline-specific and general knowledge over their study programmes. Among students, undergraduates are key category to take critical approach to provide appropriate knowledge in environmental issues.

The higher education institutes are progressively recognising that they have a vital role to play in regard to the environmental issues (de la Harpe \& Thomas, 2009). This is the reason why universities are referred as change agents that need to develop curriculum to enhance undergraduates' knowledge and skills on sustainability (Eagle et al., 2015; Mcmillin \& Dyball, 2009). Arnon, Orion \& Carmi (2014) indicated that dynamic business world supposes to educate students on environmental issues and sustainability hence, the higher education institutions play key role to cultivate the environmental literacy of undergraduates.

A cursory review of the literature shows that studies on environmental literacy have mostly focused on secondary schools (Kaplowitz \& Levine, 2005), and there is a significant lack of published research on higher education institutes (Owusu et al., 2017), especially in the context of developing nations. The studies related with environmental issues are mostly focused on consumer's intention to purchase organic food and green products (Yadav \& Pathak, 2016a: 2016b) and motivations that stimulate green consumption (Ritter, Borchadt, Vaccaro, Pereira, \& Almeida, 2015). Hence, there is still an opportunity to research on the level of environmental literacy of undergraduates. The present study aims to examine the extent of environmental literacy of commerce undergraduates in Sri Lanka. The commerce undergraduates were specifically focused because they will be future managers and decision makers in working places. The current curriculum of commerce degree programmes in Sri Lanka consists with the major environmental areas of sustainability development, sustainability reporting, green economy, environmental law, eco-friendliness, green marketing, environmental management system and corporate social responsibilities (University of Sri Jayewardenepura, 2018). Since, environmental education is an interdisciplinary concept (Roth, 1992), environmental literacy can provide through different subject areas in commerce and management disciplines. The universities, especially state universities, now highly concern to make their management graduates 
environmentally literate through degree curriculum programme. However, there is no enough published evidence on the assessment of environmental literacy level of management undergraduates in Sri Lanka. Thus, the study exposed the environmental literacy level believing that understanding the level of environmental literacy will lead to influence attitudinal changes and actions of management undergraduates towards environment. Further, the findings of the study are recommended to consider for future development of environmental education curriculum to enhance the level of environmental literacy.

The remainder of this paper is organised as follows. The first section describes the theoretical framework of the study. The subsequent section introduces the methodological design of the study. The third section presents the results of the study and the final section provides the conclusions and their implications for policy and further research.

\section{Literature Review}

The main intention of environmental literacy is to make people more knowledgeable about the environment and its associated issues such as environmental degradation and pollution (Owusu et al., 2017). According to Roth (1992, p.10), "environmental literacy is the capacity to perceive and interpret the relative health of environmental systems and take appropriate action to maintain, restore, or improve the health of those systems". However, Stables \& Bishop (2001) argued that it is not practical for all people to be educated about the environmental system, hence it is important to consider the influential roles and positions of students those who are capable to play a vital role in the society in future. Students, especially undergraduates, could be the key point of sustained change and action towards the environment. In line with that, the Sustainability Tracking, Assessment \& Rating System (STARS) version 1.2, organized by the Association for the Advancement of Sustainability in Higher Education (AASHE), indicated that higher education institutions require to assess environmental literacy of student and sustainability learning outcomes need to be incorporated into degree programmes (AASHE, 2012). Based on the premise of Owusu et al. (2017), the study refers that environmental literacy as knowledge about and an attitude towards the environment and its associated issues. In line with that, the study grouped environmental literacy 
into two exclusive categories namely general environmental factors (common environmental concerns over the world) and industry related factors (harmful effects of firms' operations and remedies offered by the relevant authorities) (Owusu et al., 2017).

According to the STARS and Goldman, Yavetz \& Peer. (2006), environmental education is vital to create an environmentally literate society. As such, it is responsibility of education institutions to ensure the efficient and effective acquisition of knowledge and skills to perform economic activities in sustainable ways (Coopey, 2003). For that reason, Omran, Yamohammadian \& Keshtiarayrancis (2014) emphasised that society expects higher education institutions to use suitable methods to attain sustainable development, growth in environmental education and institutionalize environmental knowledge, values and skills among its citizens. This calls for the examination of the level of environmental knowledge among undergraduates.

Prior studies have identified that business schools were unable to meet students, industry and societal needs in terms of environmental literacy (Jóhannsdóttir, 2009, Kaplowitz \& Levine, 2005, Lillah, 2011). Those studies argued that even though environmental and sustainability issues have become an integral part of the way, most business schools do not train their students to consider these issues as key factors in business decisionmaking. Kaplowitz and Levine (2005) examined environmental literacy level of students of University of Michigan and revealed that there were low levels of knowledge among students. The study concluded that there was minimal success in environmental education efforts over the past three decades. Jóhannsdóttir (2009) examined the environmental literacy level of MBA students at University of Iceland. The study found that MBA students have low levels of environmental literacy. In addition, Lillah (2011) conducted a survey to assess the environmental literacy level of students at the Business and Economics Faculty of the Nelson Mandela Metropolitan University. The result also indicated that environmental literacy level of business students is low, and their literacy level is limited to a few aspects of environmental literacy. This is why Hoffman (1999) complained that whilst environmental and sustainability issues have become essential parts in business world, business schools do not train their students to consider 
these issues as key factors in business decision-making. Having said so, the finding of Kaplowitz \& Levine (2005) indicated that the business faculty and business students are among the lowest scoring faculties and least knowledgeable in environmental issues. Thus, it is obvious that studies on environmental literacy in university level are limited despite society's expectations. Moreover, despite the increased recognition by management faculty in university to incorporate environmental and sustainability issues into their curriculum, the environmental literacy level of business undergraduates is still low. In this regard, this study examines the environmental literacy level of undergraduates with respect to general and industry related factors. In this regard, the present study aims to examine the environmental literacy level of commerce undergraduates in Sri Lanka, which has not been examined by prior studies.

The traditional education model (Hungerford \& Volk, 1990) indicates that when citizens are knowledgeable about the environment, it will lead them to good environmental behaviour and live sustainable life styles (Cortese, 2003). This has been investigated in different context and revealed the impact of knowledge about environment on environmental behaviour of people (Connell \& Kozar, 2012; Frisk \& Larson, 2011). However, Arnonet al. (2014) argued that it is necessary to have both environmental knowledge and attitudes, if they are to influence environmental behaviour. The study revealed a positive relationship between the environmental knowledge and environmental attitudes among 765 first-year students in three teachertraining colleges in Israel. However, Marcell, Agyemen \& Rappaport (2004) showed that familiarity of environmental knowledge does not necessarily transfer into environmental behaviour. Acknowledging that Eagle et al. (2015) indicated that student's interest in environmental issues are inconsistence due to lack of awareness of environmental damages. These controversial arguments lead the view point that there is still little evidence to support the relationship between the environmental literacy, attitude, interest and behaviour of undergraduates in higher education sector. In this regard, authors argue that environmental education ensures environmental literacy among undergraduates and it will improve their interest on environmental issues and engagement in environmental activities. Hence, the study examines whether environmental literacy influence interest in 
environmental issues and the engagement in environmental activity of management undergraduates.

Therefore, the objectives of the study were to;

- Examine the influence of environmental literacy on the actual engagement in environmental activities;

- Examine the influence of interest in environmental activities on the actual engagement in environmental activities; and

- Identify the mediating effect of interest in environmental activities on the relationship between environmental literacy and actual engagement in environmental activities of B.Com undergraduates in Sri Lanka.

\section{Research Model}

As specified by the objectives, the study intends to investigate the relationship between environmental literacy, interest in environmental issues and environmental activity engagement. Acknowledging the prior studies (Arnonet al., 2014; Connell \& Kozar, 2012; Frisk \& Larson, 2011), the study argues that an increased literacy of environment will lead to enhance the interest towards environmental issues, in turns influence undergraduates' desire to engage in environmental activities. The framework proposed in this study is illustrated in Figure 1. Accordingly, the study is constructed the following hypotheses;

H1: Environmental literacy influences the actual engagement in environmental activities of B.Com undergraduates in Sri Lanka.

H2: Interest in environmental activities influences the actual engagement in environmental activities of B.Com undergraduates in Sri Lanka.

H3: Interest in environmental activities mediates the relationship between environmental literacy and actual engagement in environmental activities of B.Com undergraduates in Sri Lanka. 
Figure 1: Research Framework

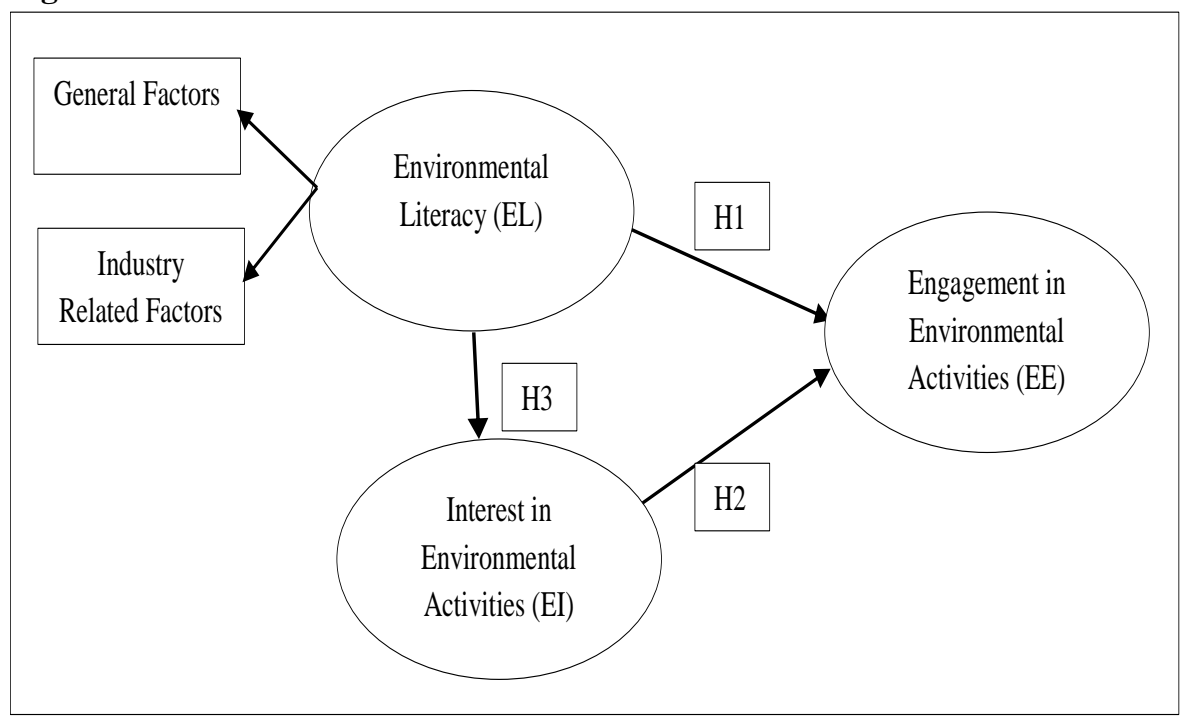

\section{Methodology}

\section{Sample and Data}

The scope of this study includes undergraduates who are enrolled with management degree programmes in state universities in Sri Lanka. There are around 15,000 undergraduates following management degrees in 15 state universities, including several management degree programmes (Business Administration, Accounting and Finance, Human Resource Management, Marketing, Information Technology, Public Administration, and Commerce). Among them, the study focused on the undergraduates who have enrolled on Bachelor of Commerce (B.Com) degree programme, since B.Com degree recognised as a multidisciplinary degree programme in management education. In total of 15 state universities, five universities are currently offering B.Com degree, counting 2,500 undergraduates. Students in four universities expressed their consent to participate in the study. The study decided to assess the level of environmental literacy of the undergraduates of Degree part III and IV. Undergraduates from Degree part I and II were not included since they do not have enough opportunity to experience the major environmental areas in their courses. Sample size was 650 students. Classification of sample in terms of university is recorded in 
Table 1. A total of 650 questionnaires were distributed to the desired sample during the second semester of the 2017 academic year. Representing 58 per cent response rate, 374 questionnaires were received. Unfortunately, none of the questionnaires were received from the representative in University of Peradeniya, which in total 94. Out of total 374 questionnaires which were analysed, 244 were females (65.2 percent), and the remaining 130 questionnaires (54.8 percent) were from males.

Table 1: Sample Classification

\begin{tabular}{lccccc}
\hline & \multicolumn{4}{c}{ University } \\
\cline { 2 - 6 } $\begin{array}{l}\text { Degree } \\
\text { Part }\end{array}$ & $\begin{array}{c}\text { Sri } \\
\text { Jayewardenepura } \\
\text { (SJP) }\end{array}$ & $\begin{array}{c}\text { Eastern } \\
\text { (EST) }\end{array}$ & $\begin{array}{c}\text { Kelaniya } \\
(\text { KLN) }\end{array}$ & $\begin{array}{c}\text { Peradeniya } \\
\text { (PERA) }\end{array}$ & Total \\
\hline Part III & 120 & 48 & 100 & 52 & 320 \\
Part IV & 116 & 52 & 120 & 42 & 330 \\
Total & 236 & 100 & 220 & 94 & 650 \\
\hline Source: & &
\end{tabular}

Source: Survey data

\section{Variables and Measures}

A self-administered structured questionnaire was used to collect data. The survey questionnaire comprised a total of 34 items, closely corresponded to the instrument used by Owusu et al. (2017), taking the cue from other studies (Jóhannsdóttir, 2009; Joseph, Nichol, Janggu, \& Madi, 2013).

The first part of the questionnaire included two categorical items which were used to solicit demographic information from the undergraduates, namely gender and place of residence. The study aimed to find whether these key demographic factors influenced the level of environmental literacy, the interest and the activity engagement of the undergraduates. The second part of the instrument used to examine the environmental literacy level of the respondents. The respondents were asked to rate their level of literacy among 20 environmental factors on a scale of 1 (very low) to 4 (very high).The 20 environmental factors consisted with nine general factors (Global warming, Greenhouse gas emission, Global climate changes, Waste management practices, Renewable and non-renewable natural resources, Energy consumption, Water wastage and water sources preservation, Environmental public complaints, and Biodiversity) and 11 industry related factors (Carbon footprint and carbon offset, Eco label, Emission trading, Environmental management system, Eco friendly production process, 
Organic agriculture, Environmental quality standards, Environmental accounting, Environmental audit, Sustainable business, and Corporate social responsibility). The final part explored the interest and activity engagement in environmental activities of the respondents. The respondents were asked to indicate their level of agreement on 14 statements using itemised rating scale (four-point Likert-scale) with end points of strongly disagree and strongly agree.

\section{Data Analysis}

The descriptive statistics were employed to examine the extent of knowledge of 20 identified factors on environmental literacy. Independent sample t-test and One-Way ANOVA were employed to ascertain the differences in level of environmental literacy, interest and activity engagement with respect to gender, academic level, university and place of residence of the undergraduates.

The proposed model for the study was estimated using regression-based path analysis (Hayes, 2012; 2013). Taking the cue from Baron \& Kenny (1986) and Hayes (2009), the regression-based path analysis follows four steps in order to assess the mediating effects of variables and their significance. Accordingly, the path coefficient between independent and dependent variables has to be significant. Likewise, the path coefficient between independent and mediating variables as well as between mediating and dependent variables should be significant. When the mediating variables are included in the model, the path coefficient between independent and dependent variables should decrease in size and has to be non-significant (Hayes, 2012, 2013; Sachitra \& Chong, 2017a; 2017b).

\section{Findings and Discussion}

\section{Goodness of the Measurement}

As preliminary step, the study assessed the validity and reliability of each variable. Content validity is ensured through reviewing literature comprehensively and critically. Composite Reliability $(\mathrm{CR}>0.7)$ and Average Variance Extracted (AVE $>0.50)$ are used to ensure the convergent validity (Hair, Sarstedt, Ringle, \& Mena, 2012). The results presented in Table 2 shows that both CR and AVE values exceed the respective threshold values ensuring the convergent validity. The discriminant validity 
was ensured as the square root values of all AVEs exceed the correlation values of the respective constructs (Fornell \& Larcker, 1981) (Table 3). Under reliability internal consistency is ensured through Cronbach's Alpha values $(<0.70)$ (Hair et al., 2012). The results are given in Table 2.

Table 2: Results of AVE, CR and Cronbach's Alpha

\begin{tabular}{lccc}
\hline \multicolumn{1}{c}{ Variable } & AVE & $\begin{array}{c}\text { Composite } \\
\text { Reliability }\end{array}$ & $\begin{array}{c}\text { Cronbach's } \\
\text { Alpha }\end{array}$ \\
\hline Environmental Literacy & 0.63 & 0.82 & .85 \\
Interest in Environmental Activities & 0.67 & 0.86 & .74 \\
Engage in Environmental Activities & 0.62 & 0.88 & .81 \\
\hline
\end{tabular}

Source: Survey data

Table 3: Values for Discriminant Validity

\begin{tabular}{llll}
\hline \multicolumn{1}{c}{ Variable } & EL & EI & EE \\
\hline Environmental Literacy (EL) & $.39^{*}$ & & \\
Interest in Environmental Activities & $.22^{* *}$ & $.45^{*}$ & \\
$\begin{array}{l}\text { (EI) } \\
\text { Engage in Environmental Activities }\end{array}$ & $.21^{* *}$ & $.26^{* *}$ & $.38^{*}$ \\
\hline
\end{tabular}

Source: Survey data

Note: *square root of the AVE; **correlation coefficient

\section{Descriptive Statistics}

Assessing the extent of environmental literacy of undergraduates with regards to general factors and industry related factors, interest in environmental issues and engagement of environmental activities were performed utilising descriptive statistics (Table 4). Accordingly, the three top indicators of general environmental literacy are water wastage and water sources preservation (Mean=2.86), global climate changes and energy consumption (Mean=2.75). On the other hand, Biodiversity (Mean=2.30) and greenhouse gas emission (Mean=2.35) were recorded the lowest mean values. In line with the industry related environmental literacy, corporate social responsibility (Mean=2.91), eco-friendly production process (Mean= 2.64) and sustainable business (Mean=2.63) were the three top indicators. Emission trading (Mean=2.10) and environmental audit (Mean $=2.20)$ are recorded as the least indicators. Concerning the overall mean value for the level of environmental literacy, it was recorded as 2.45 (with a standard deviation of 0.38 ), indicating that there was low level of environmental literacy of the selected undergraduates in this study. Further, it is worth to 
note that the overall mean value for the general environmental literacy and industry related environmental literacy are 2.62 and 2.40 respectively. Hence, these results further confirmed that there was low level of environmental literacy. The finding is in line with the arguments of Jóhannsdóttir (2009), Kaplowitz \& Levine (2005) \& Lillah (2011), emphasising that business schools were unable to meet students, industry and societal needs in terms of environmental literacy.

The overall mean value for the interest in environmental issues was 2.86, with standard deviation of 0.48 . The respondents were mostly interested in methods of enhancing environmental sustainability and community services on environmental sustainability (Mean=3.20) whereas the least environmental interest indictor was Participating in public seminars relating to environmental issues (Mean=2.35). Similarly, the overall mean value for engagement in environmental activities was 2.89, with standard deviation of 0.46 . The top indicator in engagement in environmental activities was Reduce water wastage (Mean=3.31) and least was Member of environmental clubs / organisations (Mean=2.09). Hence, the findings suggest that the level of interest in environmental issues and level of engagement in environmental activities of the selected undergraduates were moderate. These findings were corroborated with Cortese (2003), Connell \& Kozar (2012), Frisk \& Larson (2011) and Arnon et al. (2014).

Furthermore, Independent sample t-test and One-Way ANOVA were employed to identify the existence of differences in the literacy levels, interest and engagement in environmental activities between gender, academic levels, universities and place of residences (Table 4). There were two environmental interest indicators; Interest in community services on environmental sustainability and Interest in joining NGOs that deal in environmental sustainability, showed differences among males and females. Reduce water wastage, Reuse plastic and polyethene materials, and Plant trees/vegetables recorded significant differences among males and females in environmental activity engagement indicators. The indicators that showed differences in gender basis, male undergraduates recorded the highest mean values. 
With regard to the academic year, the indicator of corporate social responsibility showed the difference in environmental literacy among academic year III and IV undergraduates. The results also showed differences in three environmental interest indicators namely Participating in public seminars relating to environmental issues, Exchange views relating to environmental issues, Interest in joining NGOs that deal in environmental sustainability and Interest to study further on green economy, among third and final year undergraduates. However, there was no differences in the engagement in environmental activities with respect to the academic level basis of this study. The indicators that showed differences in academic level basis, final year undergraduates recorded the highest mean values (corporate social responsibility $=2.72$; participating in public seminars $=2.14$; exchange views relating to environmental issues $=2.49$; interest in joining $\mathrm{NGOs}=2.53$; and interest to study further on green economy=2.94). This might be occurred because final year undergraduates undertake industry related training for minimum six months. Hence, these results highlighted the importance of having industrial experience to enhance the knowledge and practice of environmental protection activities. As noted in the literature, Myers \& Beringer (2010) emphasised that changes in knowledge, attitudes and behaviours related to environment are likely to be evident as students' progress through their studies.

The study further examined differences in environmental literacy, environmental interest and engagement in environmental activities among universities selected in this study. Accordingly, there were seven environmental literacy indicators (Global warming, Global climate changes, Environmental public complaints, Carbon footprint and carbon offset, Eco label, Environmental quality standards, and Corporate social responsibility), four environmental interest indicators (Interest in methods of enhancing environmental sustainability, Interest in community services on environmental sustainability, Participating in public seminars relating to environmental issues, and Watch documentary movies relating to environmental issues on TV) showed differences. However, there was no significant difference in engagement in environmental activities among universities selected in this study. The indicators that showed significant differences in environmental literacy at university basis, the highest mean values for Environmental quality standards (Mean=2.32) and Corporate 
social responsibility (Mean=2.79) recorded from University of Sri Jayewardenepura. Kelaniya University recorded the highest mean values for Environmental public complaints (Mean=2.47) and Carbon footprint and carbon offset (Mean=1.96). Eastern University recorded the highest mean values for Global warming (Mean=2.63), Global climate changes (Mean=2.64) and Eco label (Mean=2.09). On the other hand, for the environmental interest indicators, Kelaniya University scored the highest mean values for Interest in methods of enhancing environmental sustainability (Mean=3.11), Interest in community services on environmental sustainability (Mean=3.08) and Participating in public seminars relating to environmental issues (Mean=2.18). Eastern University recorded the highest mean value for Watching documentary movies relating to environmental issues on TV (Mean=2.59).

Finally, there was no significant difference in environment literacy, interest and engagement in environmental activities in terms of place of residences of undergraduates. Thus, this result ensures that residential background could not make significant influence on environmental factors of undergraduates.

\section{Model Test}

The proposed framework of the study is tested by using the regression-based path analysis (Hayes, 2012). Table 5 shows the results of path analysis on the relationship between environmental literacy, interest in environmental activity and environmental activity engagement.

In regression-based path analysis, the path coefficient between independent (EL) and dependent variable (EE) has to be significant (model 1). Second, the path coefficient between independent variable (EL) and mediating variable (EI) (model 2), as well as between the mediating variable (EI) and dependent variable (EE) (model 3) should be significant as well. Finally, when the mediating variable is included in the model, the path coefficient between independent and dependent variables should decrease in size and has to be non-significant (Model 3). 
Table 4: Descriptive Statistics

\begin{tabular}{|c|c|c|c|c|c|c|}
\hline Factor & Mean & SD & $\begin{array}{c}\text { t } \\
\text { value }^{\mathrm{a}}\end{array}$ & $\begin{array}{c}\text { t } \\
\text { value }^{b}\end{array}$ & $\begin{array}{c}\mathbf{F} \\
\text { value }^{\mathrm{c}}\end{array}$ & $\begin{array}{c}\text { F } \\
\text { value }^{\text {d }}\end{array}$ \\
\hline \multicolumn{7}{|l|}{ Environmental Literacy } \\
\hline Global warming & 2.70 & .695 & .475 & .079 & .000 & .066 \\
\hline Greenhouse gas emission & 2.35 & .716 & .944 & .628 & .419 & .595 \\
\hline Global climate changes & 2.75 & .652 & .825 & .550 & .010 & .059 \\
\hline Waste management practices & 2.66 & .758 & .001 & .093 & .746 & .340 \\
\hline Renewable and non-renewable natural resources & 2.63 & .739 & .807 & .201 & .213 & .754 \\
\hline Energy consumption & 2.75 & .753 & .776 & .968 & .075 & .232 \\
\hline Water wastage and water sources preservation & 2.86 & .761 & .918 & .221 & .081 & .721 \\
\hline Environmental public complaints & 2.55 & .776 & .059 & .394 & .000 & .681 \\
\hline Biodiversity & 2.30 & .782 & .374 & .159 & .380 & .187 \\
\hline Carbon footprint and carbon offset & 2.20 & .827 & .941 & .885 & .033 & .599 \\
\hline Eco label & 2.16 & .756 & 522 & .370 & .000 & .439 \\
\hline Emission trading & 2.10 & .755 & .175 & .331 & .674 & .760 \\
\hline Environmental management system & 2.45 & .692 & .912 & .792 & .753 & .165 \\
\hline Eco friendly production process & 2.64 & .702 & .104 & .419 & .824 & .075 \\
\hline Organic agriculture & 2.33 & .741 & .484 & .521 & .767 & .094 \\
\hline Environmental quality standards & 2.50 & .720 & .361 & .575 & .041 & .560 \\
\hline Environmental accounting & 2.28 & .734 & .474 & .667 & .113 & .137 \\
\hline Environmental audit & 2.20 & .715 & .955 & .439 & .991 & .422 \\
\hline Sustainable business & 2.63 & .705 & .507 & .816 & .169 & .573 \\
\hline Corporate social responsibility & 2.91 & .753 & 649 & .016 & .001 & .445 \\
\hline \multicolumn{7}{|l|}{ Interest in environmental issues } \\
\hline $\begin{array}{l}\text { Interest in methods of enhancing environmental } \\
\text { sustainability }\end{array}$ & 3.20 & .664 & .226 & .199 & .003 & .145 \\
\hline $\begin{array}{l}\text { Interest in community services on } \\
\text { environmental sustainability }\end{array}$ & 3.20 & .604 & .019 & .328 & .008 & .096 \\
\hline $\begin{array}{l}\text { Participated public seminars relating to } \\
\text { environmental issues }\end{array}$ & 2.35 & .847 & .056 & .005 & .040 & .261 \\
\hline $\begin{array}{l}\text { Exchange views relating to environmental } \\
\text { issues }\end{array}$ & 2.71 & .730 & .268 & .025 & .497 & .096 \\
\hline $\begin{array}{l}\text { Interest in joining NGOs that deal in } \\
\text { environmental sustainability }\end{array}$ & 2.72 & .898 & .000 & .013 & .253 & .261 \\
\hline Interest to study further on green economy & 3.12 & .748 & .074 & .016 & .395 & .096 \\
\hline $\begin{array}{l}\text { Watch documentary movies relating to } \\
\text { environmental issues on TV }\end{array}$ & 2.77 & .847 & .569 & .329 & .028 & .158 \\
\hline \multicolumn{7}{|l|}{ Engagement of environmental activities } \\
\hline Use eco-friendly products & 2.86 & .688 & .041 & .711 & .993 & .347 \\
\hline Discourage burning of plastic and polyethene & 3.08 & .769 & .037 & .937 & .345 & .083 \\
\hline Reduce water wastage & 3.31 & .682 & .000 & .134 & .599 & .055 \\
\hline Read environmental articles in newspapers & 2.85 & .770 & .069 & .110 & .065 & .109 \\
\hline Reuse plastic and polyethene materials & 2.99 & .778 & .002 & .238 & .232 & .078 \\
\hline Plant trees/vegetables & 3.07 & .798 & .000 & .419 & .089 & .085 \\
\hline Member of environmental clubs/organisations & 2.09 & .859 & .518 & .119 & .110 & .154 \\
\hline
\end{tabular}

Source:Survey data

Note $:^{\mathrm{a}}=$ differences among males and females; ${ }^{\mathrm{b}}=$ differences among academic levels;

${ }^{c}=$ differences among universities; ${ }^{d}=$ differences among place of residences 
Table 5: Path Analysis Result

\section{Model 1}

Outcome: EE

Model Summary

\begin{tabular}{|c|c|c|c|c|c|c|c|}
\hline 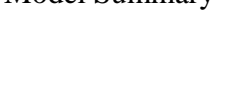 & $\begin{array}{c}\mathbf{R} \\
.2063\end{array}$ & $\begin{array}{l}\text { R-sq } \\
.0426\end{array}$ & $\begin{array}{l}\text { MSE } \\
.2033\end{array}$ & $\underset{16.5357}{\mathbf{F}}$ & $\begin{array}{c}\text { df1 } \\
1.0000\end{array}$ & $\begin{array}{c}\text { df2 } \\
372.0000\end{array}$ & $\begin{array}{c}\mathbf{p} \\
.0001\end{array}$ \\
\hline \multicolumn{8}{|l|}{ Coefficient } \\
\hline & Coeff & Se & $\mathbf{t}$ & $\mathbf{p}$ & LLCI & ULCI & \\
\hline constant & 2.2623 & 1567 & 14.4387 & .0000 & 1.9542 & 2.5703 & \\
\hline EL & .2523 & .0621 & 4.0664 & .0001 & .1303 & .3743 & \\
\hline \multicolumn{8}{|l|}{ Model 2} \\
\hline \multicolumn{8}{|l|}{ Outcome: EI } \\
\hline \multicolumn{8}{|l|}{ Model Summary } \\
\hline & $\begin{array}{c}\mathbf{K} \\
.3278\end{array}$ & $\begin{array}{l}\text { K-sq } \\
.1075\end{array}$ & $\begin{array}{l}\text { MSE } \\
.2076\end{array}$ & $\begin{array}{c}\mathbf{F} \\
44.7963\end{array}$ & $\begin{array}{c}\text { diI } \\
1.0000\end{array}$ & $\begin{array}{c}\text { df2 } \\
372.0000\end{array}$ & $\begin{array}{c}\mathbf{p} \\
.0000\end{array}$ \\
\hline \multicolumn{8}{|l|}{ Coefficient } \\
\hline & Coeff & Se & $\mathbf{t}$ & $\mathbf{p}$ & LLCI & ULCI & \\
\hline constant & 1.8211 & .1583 & 11.5028 & .0000 & 1.5098 & 2.1325 & \\
\hline EL & .4197 & .0627 & 6.6930 & .0000 & .2964 & .5429 & \\
\hline \multicolumn{8}{|l|}{ Model 3} \\
\hline \multicolumn{8}{|l|}{ Outcome: EE } \\
\hline \multicolumn{8}{|l|}{ Model Summary } \\
\hline & $\mathbf{R}$ & R-sq & MSE & $\mathbf{F}$ & df1 & df2 & $\mathbf{p}$ \\
\hline & .5655 & .3198 & .1449 & 87.2009 & 2.0000 & 371.0000 & .0000 \\
\hline \multicolumn{8}{|l|}{ Coefficient } \\
\hline & Coeff & Se & $\mathbf{t}$ & $\mathbf{p}$ & LLCI & ULCI & \\
\hline constant & 1.2925 & .1540 & 8.3942 & .0000 & .9897 & 1.5953 & \\
\hline EI & .5325 & .0433 & 12.2959 & .0000 & .4473 & .6177 & \\
\hline EL & .0289 & .0554 & .5205 & .6030 & -.0802 & .1379 & \\
\hline \multicolumn{8}{|c|}{ Total, Direct and Indirect Effects } \\
\hline \multicolumn{8}{|c|}{ Total effect of $\mathrm{X}$ on $\mathrm{Y}$} \\
\hline & Effect & SE & $\mathbf{t}$ & $\mathbf{P}$ & LLCI & ULCI & \\
\hline & .2523 & .0621 & 4.0664 & .0001 & .1303 & .3743 & \\
\hline \multicolumn{8}{|c|}{ Direct effect of $\mathrm{X}$ on $\mathrm{Y}$} \\
\hline & Effect & SE & $\mathbf{t}$ & $\mathbf{P}$ & LLCI & ULCI & \\
\hline & .0289 & .0554 & .5205 & .6030 & -.0802 & .1379 & \\
\hline \multicolumn{8}{|c|}{ Indirect effect of $\mathrm{X}$ on $\mathrm{Y}$} \\
\hline & Effect & Boot SE & BootLLCI & BootULCI & & & \\
\hline EI & .2235 & .0392 & .1499 & .3261 & & & \\
\hline \multicolumn{8}{|c|}{ Normal theory tests for indirect effects } \\
\hline & Effect & SE & $\mathbf{Z}$ & $\mathbf{p}$ & & & \\
\hline EI & .2235 & .0381 & 5.8636 & .0000 & & & \\
\hline
\end{tabular}

Source: Survey data

Model 2 (Table 5) predicts environmental interest using environmental literacy, model 3 predicts the environmental engagement using environmental interest and environmental literacy, and model 1 predicts the 
environmental engagement using environmental literacy. Model 1shows that environmental literacy was a significant predictor for environmental engagement $(\mathrm{p}<0.001, \mathrm{t}=4.07)$, supporting $\mathrm{H} 1$. Model 3 shows that environmental interest was a significant predictor for environmental engagement $(\mathrm{p}<0.001, \mathrm{t}=12.29)$, supporting H2. Further, Model 2 shows that environmental literacy was a significant predictor for environmental interest ( $\mathrm{p}<0.001, \mathrm{t}=6.69)$. However, in Model 3, environmental literacy is no longer significant in the presence of the environmental interest as a mediator $(p=0.603, p>0.05)$. Hence, the results confirm the mediating effect of interest in environmental issues on the relationship between environmental literacy and actual engagement in environmental activities, supporting H3. The value for the indirect effect of environmental interest on environmental engagement was $0.2235(\mathrm{p}<0.001, \mathrm{t}=5.87)$, which is significantly greater than zero at 95 percent confidence interval. In addition, the $\mathrm{R}^{2}$ value of model 3 (0.32) was greater than model 1 (0.04). In this case, interest in environmental issues mediates the relationship between environmental literacy and actual engagement in environmental activities of B.Com undergraduates in Sri Lanka.

The relationship between environmental literacy and actual engagement in environmental activities of undergraduates was weak but significant at 95 percent confidence interval. This is not surprising that undergraduates' literacy level of environmental factors, both general and industry-related, was low. Compare to the general factors (Mean=2.62), undergraduates' literacy level on industry related factors was very low $(M e a n=2.40)$. If environmental literacy level increases, it could be leading to upgrade the opportunities of protecting and retaining sustainable environment.

The values of the regression-based path analysis further confirmed the argument of the traditional environmental education model that connecting the knowledge level with attitude and behaviour. As the results shown (Table 5), environmental literacy will lead to influence interest towards environmental issues and in turn leads to actively engage in environmental activity of B.Com undergraduates. This finding ensures that making people more knowledgeable on environmental factors (key concept and issues) can result in promoting interest and action towards the environmental activities. This finding is in line with the arguments of Arnon et al. (2014) and Eagle 
et al. (2015), that student's interest in environmental issues are getting consistent because of obtaining awareness of environmental factors and both environmental knowledge and attitudes are essential to influence environmental behaviour. Contrasting with Marcellet, Agyeman \& Rappaport (2004), the study evidenced that familiarity of environmental knowledge does necessarily transfer into environmental behaviour.

\section{Conclusion}

The study examined the extent of environmental literacy, interest in environmental issues and engagement of environmental activities of B.Com undergraduates in Sri Lanka. According to the low mean values in overall level of environmental literacy, it is acknowledged that the findings of Jóhannsdóttir (2009), Kaplowitz \& Levine (2005), Lillah (2011) and Omran et al. (2014), indicate that environmental literacy level of management undergraduates was low. The respondents in this study were also more familiar with water wastage, CSR, global climate and eco-friendly production process. These indicators are frequently discussed subject areas in the management degree programmes in Sri Lanka. Hence, these results facilitate to recommend that B.Com degree programme should be integrated with other environmental areas such as environmental accounting and audit, emission trading, eco label and carbon footprint.

Since the respondents were mostly interested in methods of enhancing environmental sustainability and community services on environmental sustainability, undergraduates need to be encouraged to participate public seminars relating to environmental issues and watch environmental related documentaries. These can be achieved through designing the assignmentbased activities on environmental related subject areas in subject specifications.

The study established the link among undergraduates' environmental activity, environmental literacy, interest in environmental issues. It is found that environmental literacy level and interest in environmental activities are significant predictors on actual engagement in environmental activities. Hence, the study recommends that academic curriculum of B.Com degree programme needs to be integrated with more environmental areas in order to protect and retain environmental sustainability. This is in line with the 
'active learning' schema proposed by MacVaugh \& Norton (2012), indicating that it is required to move environmental concern education from mere prescription to engagement with day-to-day practices, problems and challenges that occur in real world.

Finally, the study specifically explored the mediating effect of interest in environmental activities on the relationship between environmental literacy level and engagement in environmental activities. Thus, the study ensures that making people more knowledgeable on environmental areas leads to influence interest towards environmental issues and in turn lead to actively engage in environmental activity.

From the research perspective, it is hoped that this study provides the impetus for more research to be conducted in the future. This study obtained information from only B.Com undergraduates in state universities in Sri Lanka. The valid and reliable variables used in this study can be used by other degree programmes. Further study is also required to conduct a comparative study in public and private universities in Sri Lanka. In order to enable undergraduates' attention towards environmental issues and actions, further study is required to examine the environmental literacy level among non-business undergraduates.

Besides the above limitations, the study is unique, as it is the first empirical study to examine environmental literacy level of Bachelor of Commerce undergraduates in Sri Lanka. Further, the study uniquely explored the mediating effect of interest in environmental activities on the relationship between environmental literacy level and engagement in environmental activities.

\section{Acknowledgement}

The authors thank T. D. Weerasinghe, Lecturer, Department of Human Resource Management, University of Kelaniya for his valuable contribution towards data collection of the study. 


\section{References}

Arnon, S., Orion, N., \& Carmi, N. (2014). Environmental literacy components and their promotion by institutions of higher education: an Israeli case study. Environmental Education Research, 21(7), 10291055.

Association for the Advancement of Sustainability in Higher Education (AASHE) (2012). Sustainability Tracking, Assessment and Rating System (STARS) version 1.2 technical manual. Retrieved from: www.aashe.org/files/documents/STARS/stars_1.2_technical_manual.pd f (accessed 13.08.2017).

Baron, R. M., \& Kenny, D. A. (1986). The moderator mediator variable distinction in social psychological research: Conceptual, strategic and statistical considerations. Journal of Personality and Social Psychology, 51(6), 1173-1182.

Campbell-Arvai, V. (2015). Food-related environmental beliefs and behaviours among university undergraduates: A mixed-methods study. International Journal of Sustainability in Higher Education, 16(3), 279295.

Connell, K.Y.H. \& Kozar, J.M. (2012). Sustainability knowledge and behaviours of apparel and textile undergraduates. International Journal of Sustainability in Higher Education, 13(4), 394-407.

Coopey, J. (2003). Sustainable development and environmental management: the performance of UK business schools. Management Learning, 34(1), 5-26.

Cortese, A.D. (2003). The critical role of higher education in creating a sustainable future. Planning for Higher Education, 31(3), 15-22.

de la Harpe, B.,\& Thomas, I. (2009). Curriculum change in universities. Journal of Education for Sustainable Development, 3(1), 75-85.

Eagle, L., Low, D., Case, P. \& Vandommele, L. (2015). Attitudes of undergraduate business students toward sustainability issues. International Journal of Sustainability in Higher Education, 16(5), 650668.

Fornell, C., \& Larcker, D. F. (1981). Structural equation models with unobservable variables and measurement error-algebra and statistics. Journal of Marketing Research, 18(3), 382-388. 
Frisk, E., \& Larson, K.L. (2011). Educating for sustainability: competencies and practices for transformative action. Journal of Sustainability Education, 2(1), 1-20.

Goldman, D., Yavetz, B.,\& Peer, S. (2006). Environmental literacy in teacher training in Israel: Environmental behaviour of new students. The Journal of Environmental Education, 38(1), 3-22.

Hair, J. F., Sarstedt, M., Ringle, C. M., \& Mena, J. A. (2012). An assessment of the use of partial least squares structural equation modelling in marketing research. Journal of the Academic Marketing Science, 40, 414-433.

Hartman, C.B., DeMars, C.E., Griscom, H.P., \& Butner, H.M. (2017). Assessment of undergraduate students' environmental stewardship reasoning and knowledge. International Journal of Sustainability in Higher Education, 18(4), 492-502.

Hayes, A. F. (2012). PROCESS: A versatile computational tool for observed variable mediation, moderation, and conditional process modeling [White paper]. Retrieved from: http://www.afhayes.com/ public/process2012.pdf (Accessed 20/04/2016).

Hayes, A. F. (2009). Beyond Baron and Kenny: Statistical mediation analysis in the new millennium. Communication Monographs, 76(4), 408-420.

Hayes, A. F. (2013). Introduction to mediation, moderation, and conditional process analysis: A regression-based approach. New York: Gailford Publications.

Hoffman, A.J. (1999). Commentary: environmental education in business school. Environment: Science and Policy for Sustainable Development, 4l(1), 4-5.

Hungerford, H.R., \& Volk, T.L. (1990). Changing learner behaviour through environmental education. The Journal of Environmental Education, 21(3), 8-21.

Jóhannsdóttir, L. (2009). Environmental literacy of business students, Working Paper Series, Institute of Business Research, University of Iceland, Reykjavík.

Joseph, C., Nichol, E.O., Janggu, T., \& Madi, N. (2013). Environmental literacy and attitudes among Malaysian business educators. International Journal of Sustainability in Higher Education, 14(2), 196208. 
Kaplowitz, M.D., \& Levine, R. (2005). How environmental knowledge measures up at a big ten university. Environmental Education Research, 11(2), 143-160.

Lillah, R. (2011). Environmental literacy: A needs analysis. Port Elizabeth: Nelson Mandela Metropolitan University, p. 298.

MacVaugh, J., \& Norton, M. (2012). Introducing sustainability into business education contexts using active learning. International Journal of Sustainability in Higher Education, 13(1), 72-87.

Marcell, K., Agyeman, J., \& Rappaport, A. (2004). Cooling the campus: experiences from a pilot study to reduce electricity use at Tufts University, USA, using social marketing methods. International Journal of Sustainability in Higher Education, 5(2), 169-189.

Mcmillin, J., \& Dyball, R. (2009). Developing a whole-of-university approach to educating for sustainability. Journal of Education for Sustainable Development, 3(1), 55-64.

Myers, O. E., \& Beringer, A. (2010). Sustainability in higher education: psychological research for effective pedagogy. Canadian Journal of Higher Education, 40(2), 51-77.

Omran, M. S., Yarmohammadian, M. H., \& Keshtiarayrancis, N. (2014). Integrated approach: a suitable approach for designing and developing an environmental literacy curriculum in higher education system. Entrepreneurship and Innovation Management Journal, 2(1), 84-96.

Owusu, G. M. Y., Kwakye, T. O., Welbeck, E. E., \& Ofori, C. G. (2017). Environmental literacy of business students in Ghana. International Journal of Sustainability in Higher Education, 18(3), 415-435.

Petocz, P., \& Dixon, P. (2011). Sustainability and ethics: graduate dispositions in business education. Asian Social Science, 7(4), 18-25.

Ritter, A.M., Borchardt, M., Vaccaro, G.L.R., Pereira, G. M., \& Almeida, F. (2015). Motivations for promoting the consumption of green products in an emerging country: exploring attitudes of Brazilian consumers. Journal of Cleaner Production, 106, 507-520.

Roth, C.E. (1992). Environmental literacy: Its roots, evolution and directions in the 1990s.Columbus: ERIC Clearinghouse for Science, Mathematics and Environmental Education.

Sachitra V., \& Chong, S. C. (2017a). Relationships between institutional capital, dynamic capabilities and competitive advantage: Empirical 
examination of the agribusiness sector. International Review of Management and Marketing, 7(1), 389-397.

Sachitra V., \& Chong, S. C. (2017b). Collective action, dynamic capabilities and competitive advantage: Empirical examination of minor export crops sector in Sri Lanka. Journal of Economics, Management and Trade, 20(3), 1-15.

Stables, A., \& Bishop, K. (2001). Weak and strong conceptions of environmental literacy: Implications for environmental education. Environmental Education Research, 7(1), 89-97.

University of Sri Jayewardenepura (2018). Prospectus 2018 - Faculty of Management Studies and Commerce. Sri Lanka.

Yadav, R., \& Pathak, G.S. (2016a). Intention to purchase organic food among young consumers: Evidences from a developing nation. Appetite, 96,122-128

Yadav, R., \& Pathak, G.S. (2016b). Young consumers' intention towards buying green products in a developing nation: Extending the theory of planned behaviour. Journal of Cleaner Production, 135, 732-739. 